\title{
Forum
}

\section{Meditations after the fire: Scholars on Notre Dame}

postmedieval: a journal of medieval cultural studies (2019) 10, 513-526.

https://doi.org/10.1057/s41280-019-00149-5

In the wake of the fire that broke out in Notre Dame Cathedral Paris on April15, 2019, and captivated global concern, six scholars reflect on the cathedral's past and its soundscape and significance today.

\section{Some reflections from Ground Zero}

\section{Anna Russakoff}

Department of Art History and Fine Arts, American University of Paris, Paris, France

Since I live in the suburbs of Paris and do not have a TV, I learned about the fire in much the same way that I found out about the 2015 terrorist attacks: I picked up my phone to discover a series of frantic text messages. For the terrorist attacks, they were mostly 'are you OK?' and for the fire it was 'I can't believe what's happening to Notre Dame; you must be so upset.' During the evening of April 15, before the fire was under control, I feared along with everyone else that the building was not going to survive the night.

I have lived in Paris for thirteen years. I have taken students to Notre Dame every semester and led countless private tours there as well. I developed my own routine. We'd go inside, admire the monocylindrical columns and the sexpartite vaults. We'd discuss 3-story vs. 4-story elevations. At the crossing we'd see one 
of my favorite statues, the elegant 14th-century 'Vierge de Paris.' Then we'd observe the Rayonnant rose windows in the transept from the inside. We would proceed through the ambulatory, looking at the recently cleaned 14th-century choir enclosure relief sculptures, contrasting them to the 17 th-century woodwork in the interior, and imagining the former choir screen. Further along we'd study the two wooden maquettes of the building, and the hypothetical reconstruction of the original working site. Recently they installed instructive panels based on the work of scholars Andrew Tallon and Dany Sandron, outlining all the major phases of the building of Notre Dame.

Then we'd head outside, towards the south transept. The south rose is by far my favorite part of the building, and the best way to understand the Rayonnant style. We'd go around the back to admire the flying buttresses, impressive even if they aren't original. The north side offers gargoyles (mostly also unoriginal), the two Theophilus reliefs, and the Porte Rouge. We'd do our best with the west façade, although it was always difficult because of the crowds; we'd see what we could from 'ground zero,' the central point from which all distances in France are measured. This was usually a good place to discuss the original polychromy of the façade sculptures and the fate of the Gallery of Kings during and after the French Revolution. In 2016, as part of a conference run by the British Archaeological Association, I got to see Pierre de Montreuil's signature on the south transept, to walk along the triforium, and to climb up to the lower roof just above the buttresses for a calm, spectacular view of Paris - privileges rarely granted to those of us who are not architectural historians. In so many ways, Notre Dame was beginning to feel like it was 'mine.'

With one big caveat. As a Jewish American, the Cathedral of Notre Dame holds no religious significance for me. Although I have attended world premier organ concerts there, I have never attended a Mass. The fire at Notre Dame has made me reflect on the religious minorities of France, and how our monuments fail to define the city. For example, the early 20th-century 'Grande mosquée de Paris' is located in the eastern part of the 5e arrondissement; it is in central Paris, but is certainly not considered 'the center.' I have never heard its minaret referred to as 'an iconic part of the Parisian skyline.' The law forbidding the headscarf in public schools and government buildings makes it perfectly clear that being a practicing Muslim is 'not French.' If a fire ravaged this mosque, hardly the same kind of discourse - or fundraising - would take place afterwards.

Protestants have also had a troubled history in France. My father-in-law, a French Huguenot, was always reminded on August 24 of the date of the St. Bartholomew's Day Massacre in 1572. Mostly following the Calvinist tradition, French Protestant churches are modestly decorated. The American Church of Paris, which is Protestant, stands one block from my office in the 7e arrondissement. Constructed in the early 20th century in the Neo-Gothic style, it has a spire, but one that is dwarfed by the Eiffel Tower, less than a mile away. 
It is known only by those who live or work in the neighborhood. Protestant churches in France also tend to have many parishioners of color, which is not something that I ever observed at Notre Dame.

The 'Grande Synagogue de Paris' is in the 9e arrondissement, and its presence served as a comfort for me when I lived in that neighborhood while researching for my dissertation. Constructed in the 19th century in an eclectic, NeoByzantine style, and classified as a World Heritage site, it is not 'set off' from the street as a separate monument. Most other synagogues in France are forced into even more discretion. In the town where I currently live, the synagogue is a nondescript brick structure tucked away on a side street. Why? Although France has both the oldest and the largest Jewish population in Europe, anti-Semitism, present for centuries, has seen an alarming rise. On the Ile-St.-Louis, a bagel shop was recently sprayed with Nazi graffiti. Similar defacements occurred on a poster of Simone Veil, and in a Jewish cemetery in Alsace. And these are just a few incidents from the past months. Sadly, if a synagogue in France burned, no one would assume that it was an accident.

Of course, everyone is grateful for the funds that have poured in already to restore Notre Dame. But they also exacerbate tensions concerning huge economic disparities, tensions that are currently polarizing the population in France. One salient theme of the 'yellow vest' movement has been dissatisfaction over sharp inequalities. As the French billionaire families Pinault and Arnault pledge 100 and 200 million euros respectively to the restoration, many French people can barely make it to the end of the month, and unemployment remains high. Rather than bringing everyone together, these extraordinary pledges following the fire did nothing to stop the Saturday protests. Ambivalence prevails: on the one hand, I want as much funding as possible to restore Notre Dame to magnificence; on the other hand, there are many other people and causes that need this money badly.

The Cathedral of Notre Dame, heavily restored in the 19th century, was already an amalgam of styles prior to April 15, 2019. It is therefore impossible to return to a 'true' medieval original. ${ }^{1}$ Yet I hope that as much of the standing structure as possible will be preserved, and that the contemporary additions will

1 See Easton and Borland (2018). remain in good taste and will 'harmonize the old with the new,' as Abbot Suger envisaged for his reconstruction of the abbey church of St.-Denis. President Macron's goal for Notre Dame to be rebuilt in five years - not coincidentally in time for the 2024 Olympics - seems too hasty. Restoration decisions for such a significant monument deserve time for reflection, in consultation with expert opinions from historians, architects, and restorers from all over the world. And important as it is for so many people for so many different reasons, we should also take a moment to remember that Notre Dame is just one center among many. 


\title{
Stone Grieving
}

\author{
Coll Thrush
}

Department of History, University of British Columbia, Vancouver, Canada

For me, it was the spire that did it. Tourists and residents alike filmed and then posted the blazing collapse of Notre Dame's nineteenth-century Gothic Revival spire, and it was the unscripted and collective cries of anguish, surprise, and wonder - stunned crowds on a boat in the Seine, horrified neighbours in a street near the cathedral - that most provoked my own response to the partial destruction of one of the world's most beloved landmarks. Responses to the burning of Notre Dame were quick. French president Emmanuel Macron, Pope Francis, and countless other world leaders immediately committed to rebuilding and expressed their deep grief at the seeming loss of a Christian icon. And it is the question of grief - along with related concerns around history, colonialism, and empathy - to which I attend here.

The same week that the cathedral burned, thousands of miles away, a parallel crisis was looming in a place called Chaco, in the northwestern part of what is currently known as New Mexico. The wide, cliff-encircled canyon at Chaco is home to dozens of great houses and other structures, most of them contemporaries with, or older than, Notre Dame. Many appear to be aligned with astronomical phenomena, just as Notre Dame is aligned to the rising sun symbolizing the second coming. Much of Chaco Canyon is protected as a national historical park, and Hopi, Pueblo, and other nearby Indigenous communities and nations continue to assert religious connections to the structures. On my first visit to Chaco, for example, I encountered a couple speaking their language into the stones of one of the structures. As I quickly retreated from their private moment, I understood it as a clear and unambiguous expression of the canyon as ancestral space, in which rock is, quite literally, involved in conversation. But in that same year, the federal government announced that additional oil and gas leases would be allowed on public lands in and around the canyon, drawing the ire and organized resistance of Indigenous and non-Indigenous people alike.

Even before the fire in Paris had turned to cold ash, many Indigenous scholars and activists, along with some non-Indigenous observers, pointed out the disjuncture and dissonance between the overwhelming global response to what appeared to be an accident and widespread ignorance about and disinterest in deliberate attempts to extract fossil fuels from an equally old, equally complex, and equally active sacred space. In one podcast, for example, Indigenous scholars Candis Callison (Tahltan) and Kim TallBear (Sisseton Wahpeton Oyate) identified the problem as a 'grief gap' (Media Indigena, 2019). Their 
words resonated with a powerful critique of colonial consciousness that resides near the heart of Indigenous studies as a field: the analysis of the 'ungrievability' of the Indigenous, most explicitly articulated in Jodi A. Byrd's foundational book The Transit of Empire. There, the Chickasaw scholar speaks to the agenda for a critical historical consciousness that 'depend[s] upon memory and imagination to grapple with and create the possibility for grievability in the face of mass death' (Byrd, 2011, 83). This need to mourn Indigenous loss, meanwhile, is at odds with the deep amnesia, aphasia, and agnosia that undergird the storytelling that settler colonialism does (Vimalassery et al, 2016). And of course, the global influence of Christianity, represented in structures like Notre Dame, is at the very centre of these historical and ongoing processes.

As I write this, Kānaka 'ōiwi (Indigenous Hawaiian) people and those in solidarity, among them friends and colleagues, are encamped high on the slopes of Mauna Kea ('White Mountain') on the Big Island, where a multinational consortium of universities, including my own, have proposed the construction of a fourteenth astronomical telescope atop the Mauna, which is well attested as kapu or sacred ground for Kānaka 'ōiwi since around the time that Notre Dame was completed, and is covered by the National Historic Preservation Act. One form of protest has been to build ahu or stone cairns in the way of construction; these structures echo ancient ahu found across the high places of Hawai'i. Another has been to create a pop-up university at Pu'uhonua Pu'uhuluhulu, where experts share knowledge, including astronomical teachings, with the people gathered there. These efforts have galvanized international attention and action. And so here, as at Chaco, it is irresponsible to talk about the effects of empire - for example, the relationship between the American real estate economy and Kānaka 'ōiwi homelessness in 'paradise' - without also acknowledging the profound cultural and political resurgence happening at places like Mauna Kea. We should not speak of settler colonialism without also amplifying Indigenous survivance and futurity. As Kānaka 'ōiwi scholar Iokepa CasumbalSalazar writes, the resistance at Mauna Kea 'is a story about the future we imagine for ourselves and our ancestral homelands' (Casumbal-Salazar, 2017, 25).

We must also insist on the contemporaneity of European and Indigenous histories, medieval and otherwise. Jeffrey Jerome Cohen has written that 'stone is seldom inert.' Rather, it is '[f]ull of relation, teeming with narrative' (Cohen, 2015, 22). The stones of Notre Dame, Chaco Canyon, and Mauna Kea are each infused with centuries of human affect: joy, gratitude, reverence, and yes, grief. And each site is a connection to the stars: the liturgical east of the rising sun in Paris, the equinoctial orientation of great houses at Chaco, and the constellations that brought the ancestors to Hawai'i in their great sailing vessels. The stones of these places - like networks of colonial and other forms of power connect them to the sky and to similar numinous sites across the planet. They 
2 Archive of the Abbey of Averbode, sect. I, reg. 107 , f. $75 r$.

3 Archive of the Abbey of Averbode, A-I-IV, sect I, reg. 4, f. $143 v$. bring stars to ground while calling us to look upward but also to each other for empathy, renewal, and guidance.

To learn more about ongoing efforts to preserve Chaco Canyon, visit frackoffchaco.org, and to support the protectors at Pu'uhonua Pu'ubulubulu, go to www.protectmaunakea.net.

\section{Sequenza for Notre Dame}

\section{Matthew S. Champion}

Institute for Religion and Critical Inquiry, Australian Catholic University, Melbourne, Australia

'Writing for a single-voice instrument today means that the composer must thoroughly re-establish the relationship between open and concealed, linear and melodic counterpoint from the ground up' - Luciano Berio, introduction to 'Sequenza I'

Events re-sequence time. The last time I was in Notre Dame was for the Easter Vigil Mass in 2008. The whole place was packed and in darkness, and we had to perch half-way up the base of a huge pillar in the nave. From there we saw the great west doors thrown open and a wall of fire and rising sparks raging outside. They were prayers gathered into a huge bonfire, the new fire for the Easter candle. Around the fire you could just make out the shapes of the pompiers gathered in case something went wrong. Then, in front of the blaze, a single light wavered inside the cathedral, and then a wave of candle-points started to spread down and over the nave. The cathedral flooded with fire. At the end of the service another kind of fire, too, leapt from the great organ: a vast improvisation on the Easter sequence Victimae paschali laudes ('The Praises of the Easter Victim').

Some years later I made a visit to the Abbey of Averbode in modern Belgium. I was there because of another fire. The Abbey's Obituary gives the details. ${ }^{2}$ It was night, the year 1499, and the feast of St Crispin and St Crispinian, between 8 and $9 \mathrm{pm}$. Lightning strikes the Abbey church, sparking a conflagration. After the flames die down, amidst the ashes of the ruined church lie the broken bells of the Abbey. Bell founders came from 's-Hertogenbosch to comb the ruins for scrap metal to salvage for new bells and a clock, a clock that would include a novel technology for playing fragments of liturgical chant on small bells. ${ }^{3}$ Each hour, the bells of the clock were to chime a prayer for the descent of tongues of fire, the Pentecost sequence Sancti Spiritus assit nobis gratia ('may the Holy Spirit be present to us with grace'). On the half hour, they played that same 
sequence I heard in Paris, with the new text Virgini Mariae laudes ('The Praises of the Virgin Mary').

Among the manuscripts at Averbode are some leaves from a thirteenthcentury Antiphonal. ${ }^{4}$ Someone, sometime after their creation, has written in the margins campana terroris ('bell of terror') and its Flemish equivalent, storm clock ('storm bell'). Those bells could drive away the lightning, protect against fire - but their sound could also be a horror. Were the bells at Averbode ringing against the coming storm in 1499? As Notre Dame burned, the Archbishop of Paris called for bells to ring out, too, to invite prayer. ${ }^{5}$ Would the sound of those bells be a comfort or a terror? Or maybe a comfort and a terror, the habitual notes made for a moment a thousand times more resonant? Did a similar amplification happen for those watching the fire who sang the Ave Maria, even as these sounds were transformed into a global commodity, streamed on live news feeds, interpolated into news reports, able to be lived again and again on YouTube, with emotions amplified and diminished, sequenced and re-sequenced in a virtual world gathered around a new fire? ${ }^{6}$ Something of the horror of the bells can be sensed now scrolling back through the live blogs of the fire. I felt it that night. What if the fire reached the bell towers and those massive objects, born in fire, fell, their weight tearing out the supports of the towers and bringing the soaring towers crashing down? The noise of the spire falling was horror enough - but the descent of that sweet weight suspended there between heaven and earth would have its own particular terror. I had seen bells that had fallen before in another Notre Dame, in Lübeck, where they were left strewn on the floor, bronze like melted chocolate on the floor of the church. That happened on Palm Sunday, 1942.

Averbode had its own disaster in 1942, but more banal than an allied bomb raid. Fire starting in the kitchens ravaged the Abbey again, on 29 December, the feast of Thomas Becket. There's a beautiful seventeenth-century book of maps in the Abbey's archives, and a modern hand has noted the details of this new fire date, time, extent of destruction. ${ }^{7}$ All of it is in the same form as the Obituary's record of the fire of 1499. Two different times brought together in this small act of memoria. The little text, hidden inside the cover of the book, seems to be telling us that 1499 and 1942 are not so far apart. The start of a new sequence, or the end of one.

Different voices, different times brought together. At Notre Dame in the late twelfth century, new music did the same thing. And this involved sequences, too: Perotin's famous Viderunt omnes is laden with melodic series, great arches of sequential repetition in and between voices, grounded in the chant. It seems as solid as stone and as intricate as gothic tracery. But it is fragile, too - I sang it once in a small concert in a dark room, where the singers in the round were watched over by the audience. If anything goes wrong, the sound falters and the architecture begins the crumble. It is frightening. But if you meet the other voices
4 Archive of the Abbey of Averbode, ms IV, 417, 17.

5 See Lyons and Busby (2019).

6 For an example, see https://www. youtube.com/ watch?v= FGf8r2JSeuw.

7 Archives of the Abbey of Averbode, sect. I, reg. 106. 
at each cadence, you'll keep standing to the end. And it's an astonishing revelation.

\section{The Medievalist Soundscape of Notre Dame of Paris (and What Remains Unchanged)}

Kacie Morgan

Department of Musicology, University of California Los Angeles, Los Angeles, USA

As the news continues to develop concerning the aftermath of the fire at Notre Dame Cathedral, it cannot be denied that our relationship to this important site in Western music history has once again changed. The repair and reconstruction of the lost roof and spire will change the soundscape of the cathedral in any number of ways. As the fire raged, medieval musicologists were already preparing to mourn the loss of a medieval soundscape, as they emphasized the centrality of Notre Dame and its twelfth-century composers Leonin and Perotin to the standard narrative history of Western music history. Yet, the question that arises for me is, which version of the medieval soundspace did we lose?

The soundscapes of twelfth-century composers Leonin and Perotin have already been lost to us for some time now. Leonin is known for composing many early organum settings, a polyphonic texture in which one voice sings melismatically above a held tenor voice (Yudkin, 1985). Leonin's last appearance in archival records is in 1201, so he would not have seen the completion of the cathedral space in 1220 (Wright, 1989, 11). At the end of the twelfth century, Perotin is reported to have begun composing discant, a highly rhythmicized polyphonic texture (Yudkin, 1985; Wright, 1989). Perotin's presence in the record ends in the 1240s or 1250s, meaning that he likely did see the completion of the nave and towers (Payne, 2016; Wright, 1989, 291). However, he would have missed the completion of new construction projects in the thirteenth and fourteenth centuries, including the addition of lateral chapels, the enlarging of the windows, and the later widening of the transepts (Doquang, 2011; Bruzelius, 1987). These three alterations to the space would have produced a substantial shift in the soundscape, creating more volume to fill sonically, not to mention the temporary loss of sound-reflecting surfaces, as the windows were removed and the walls were taken down to make room for larger windows. With these architectural changes, the soundscape in which the rhythmic and harmonic experimentation of Leonin's organum and Perotin's discant took place was forever changed.

We cling to the soundscape of the modern-day cathedral as we have experienced it, and we imagine that soundscape as medieval, despite the many 
changes that have occurred. It represents what was once there musically and physically. This identification of the cathedral's pre-fire soundscape as medieval is in part due to the renovators Jean-Baptiste Lassus' and Eugène Viollet-leDuc's reincorporation of twelfth-century elements, such as a version of the fourpart elevation - consisting of the aisle, gallery, oculus window, and clerestory window - which can be seen transitioning into, and out of, the transept of the cathedral (Erlande-Brandenburg, 1998, 225). This element simultaneously provides a connection to the earliest version of the cathedral and changes its acoustics yet again. Viollet-le-Duc simultaneously altered floor heights, added aesthetic design elements for uniformity (such as sculpture and gargoyles), and retained thirteenth-century and later revisions of the architecture, creating a nineteenth-century version of the medieval space (Tallon and Sandron, 2013, 158-71; Erlande-Brandenburg, 1998, 218-35). This version of the cathedral is the one often recalled by current scholars and those who love the cathedral today.

The importance of Notre Dame cathedral to many fields of study (not to mention the additional layers of its cultural and, now, political significance and global visibility after the fire) raises the stakes of the current restoration. Many of us feel invested in how the restoration will be carried out. From a musical and acoustic perspective, current repairs will alter the acoustics of the space once again. The new soundscape will depend on the materials put in place, the thickness of the stone and mortar, and the shaping of the vaults. Yet no matter what the outcome of the new stone vaulting, our relationship to the medieval soundscape remains in some ways unchanged: that is, the truly medieval soundscape continues to be outside our grasp. The soundscape of the late twelfth and early thirteen century and the performance conditions during this time will remain lost to us. The completion of the new vaults will foster a new layer of meaning for our experience, as the new soundscape is compared to memories of the pre-fire conditions. Will we be able to hear the difference? The current renovations, like the others, will simply become part of a new soundscape of the cathedral.

\section{A Cathedral's Soundscapes of Violence}

\section{Una McIlvenna}

School of Historical and Philosophical Studies, University of Melbourne, Melbourne, Australia

The recent sight of Parisians singing hymns outside the burning cathedral of Notre Dame was for most of us a moving response to the endangerment and 
partial destruction of a sacred institution. However, for me, as a researcher of ballads about crime and public execution in the early modern period, Notre Dame Cathedral is not only a place I associate with peaceful worship but also one whose history echoes with the sounds of brutal punishment, with the voices of those preaching hatred of the heretic, and with satirical songs mocking enemies.

Although in Paris the Place de Grève and the Place Maubert were more regularly used as execution sites in the early modern period, many condemned criminals were still forced first to make their amende honorable, or their public confession and apology made wearing only a smock and with head uncovered, in the parvis, or porch, of Notre Dame Cathedral. Mme Sévigné thus described the scene at the execution ritual for the Marquise de Brinvilliers, convicted in 1676 of poisoning her family: 'At six o'clock she was taken, naked in a shirt and with the cord around her neck, to Notre Dame to make the amende honorable; and then she was put back in the same tumbril, where I saw her. [. . .] Never were seen so many people, nor was Paris so moved yet so attentive' (Sévigné, 1676).

Other crimes were judged suitable for the execution to take place at the cathedral itself. In 1548 Jacques Belon was condemned to be executed in front of Notre Dame because he had attacked an image of the Virgin in her own church (Nicholls, 1988, 54). The execution of Jean Thuret, who in 1550 also attacked a statue of the Virgin in the cathedral, was accompanied by a procession through the city that included the canons of Notre Dame and the counsellors of the parlement in full ceremonial regalia, while the bells of Notre Dame rang out. The procession began and ended in front of the cathedral, culminating with mass inside (Nicholls, 1988, 61). This kind of attack on ritual objects within the cathedral seems to have happened with some frequency. On 3 August 1670, François Sarazin murdered a priest with a sword on the altar of Notre Dame, then knocked over and trampled the host and wine. He was sentenced to an amende honorable, to have his hand cut off in front of the cathedral, and then to be burned alive and his ashes scattered. A complainte, or ballad about his actions, describes his punishment in detail:

Il me faut amande honorable Faire pour ma punition, Dedans l'Eglise Cathedralle, Où j'ay fait la noire action, Et puis le point couppé aussi Ensuitte mes jours accourcy. (Execution remarquable, 1670)
I must perform an amende honorable For my punishment, Within the Cathedral church, Where I committed the black deed, And then my hand cut off too Then my days to be shortened. 
It wasn't only violence within the cathedral that was punished there. On 26 February 1587, the seventy-year-old Italian Dominique Miraille, who had been concierge to the Princesse de La Roche-sur-Yon, one of the queen mother's most powerful ladies-in-waiting, was convicted of sorcery along with his mother-inlaw, and was sentenced to be hanged and then burned on the parvis of Notre Dame (L'Estoile, 1992, vol V, 267). Presumably the threat of sorcery to the religious status quo was justification enough for this punishment to take place there.

It was the Protestant Reformation during the late sixteenth century, however, that presented the greatest threat, and Paris, a resolutely Catholic city, would regularly burn Huguenots in front of Notre Dame. Often these punishment rituals were included in larger state-sponsored ceremonies that culminated in mass celebrated in the cathedral. The burnings of heretics after the Affair of the Placards in 1534 and during Henry II's Parisian entry of 1549 were prefaced by huge processions involving the royal family, the sovereign courts, university officials, religious orders, municipal government, and notable bourgeois and merchants. Singing hymns, they wound their way through the city to Notre Dame, where bells once again rang out (Nicholls, 1988, 60-61). ${ }^{6}$ Moreover, the bloody violence against heretics was inspired from within the cathedral itself. The virulently anti-Huguenot preacher Simon Vigor delivered a sermon there in 1571 to celebrate the recent abolition of the unpopular Edict of Pacification, which, while it lasted, had afforded some small protection to Protestants. Vigor registered his approval for the king's new order that any Protestant minister who had not left the kingdom within the allotted interval might be killed on sight (Diefendorf, 1987, 405).

As this account suggests, the sounds from within, about, and around Notre Dame Cathedral in the early modern period were just as likely to be the sounds of violence, hatred, ridicule, and pain as the peaceful hymns we associate with it today. As debate swirls around the fate of Notre Dame post-fire and what its role should be in a city much changed since its original construction, we would do well to remember how Parisians have long gathered there for intensely emotional reasons: to perform Te Deums in celebration of military victories, to sing about the brutal mutilation of criminals, and to ring bells to celebrate the violent murder of heretics. In a world that seems to have recently gone crazy, the fire at Notre Dame appeared to many of us like the last straw, an attack on one of the few good things that were left. But perhaps we can draw some steadiness from knowing that there has always been violence and division around this place, and that the cathedral - and the world - have survived and carried on. 


\title{
Reconstructing Notre Dame
}

\author{
Constant J. Mews
}

School of Philosophical, Historical, and International Studies, Monash University, Clayton, Australia

The first images of the fire at Notre Dame hit Australian television screens in the early morning of 16 April 2019. Like many, I could not believe what I saw. This is the building that has served as a central axis for my teaching of medieval culture. It has dominated the Île-de-la-cité since Bishop Maurice de Sully first proposed, in 1163, that a building in a radically new style replace the original cathedral of the city of Paris. While nothing is left of the royal palace on the island (apart from the magnificent Sainte Chapelle, now largely concealed from public view), the elegant flying buttresses of Notre Dame and that iconic spire are clearly visible from both sides of the river. They have long provided to citizens and tourists alike an image of calm confidence in the stability of medieval civilisation. It was a shock to have that image challenged. Over the next few days, as I had to prepare for numerous radio interviews about the significance of Notre Dame, I came to realize how profound was the influence of that building on people who did not know much at all about the Middle Ages. By virtue of its location and public accessibility, that was perhaps the most visited church in the world, delivering an experience of the sacred to the religious and the unchurched alike.

Speaking on the radio about the importance of Notre Dame in terms of its architecture was so much more satisfying than the other subject I had been asked to speak about to the media in the previous weeks, namely the conviction of Cardinal George Pell on charges of child abuse, while he was archbishop of Melbourne. Yet I could see that what fascinated the media was not dissimilar, namely that an institution once proudly confident of its position in society was now crumbling in the face of the crimes against children it had for so long failed to acknowledge. With the fire at the cathedral, however, negligence did not lead - thank God - to loss of human life. The media could cast its ability to survive, even without its roof or spire, as a minor miracle, even if it was the firefighters to whom our thanks are due.

I knew a good deal about the building of Notre Dame as marking a radically new departure in ecclesiastical architecture. It relied on structure rather than thick walls to support its roof. Whereas Abbot Suger had first experimented with a new style at Saint-Denis, he never completed the task. It was in this cathedral where new forms of polyphony were first developed in the late twelfth and thirteenth centuries. Architectural innovation encouraged composers to 
conceive liturgical music differently. Ancient Latin plainchant became interlaced with other, quite different melodies, sometimes with vernacular texts. Even if tourists ambling through the building might not pick up all these resonances, the cathedral still used recordings of sacred music to maintain an appropriate ambiance. The free organ recitals on Sundays at $5 \mathrm{pm}$ were always packed. For an hour, a magnificent instrument provides an experience of musique totale.

The music has now stopped, for a few years at least. The fire made me realize that the building so many of us have revered as medieval is in fact the legacy of Victor Hugo, who first alerted Parisians to the sorry state of decay into which it had fallen, through his novel Notre-Dame de Paris (1831), translated into English as The Hunchback of Notre Dame. The spire which collapsed in 2019 was in fact a key feature of the reconstruction (1844-64) envisaged by Eugène Viollet-le-Duc in response to Victor Hugo's campaign to pay attention to the cathedral's tarnished state after the Revolution.

My suspicion is that the astonishing speed with which funds have been collected to rebuild the cathedral, much greater than those collected for refugees in France, will serve to create a similar new awareness of a building that is still revered by the most fervent adherents of laicité. The music (and the candles) will return, although with greater attention to security and fire alarms. Whether the structure of the institution that the building serves will regenerate in a similar fashion is uncertain. For the moment, the process of rebuilding Notre Dame will give those who visit Paris a more authentic experience of medieval cathedrals in general. They were always under construction.

\section{References}

Bruzelius, C. 1987. The Construction of Notre-Dame in Paris. The Art Bulletin 69(4): 540-569.

Byrd, J. A. 2011. The Transit of Empire: Indigenous Critiques of Colonialism. Minneapolis, MN: University of Minnesota Press.

Casumbal-Salazar, I. 2017. A Fictive Kinship: Making 'Modernity,' 'Ancient Hawaiians,' and the Telescopes on Mauna Kea. Native American \& Indigenous Studies 4(2): 1-30.

Cohen, J J. 2015. Stone: An Ecology of the Inhuman. Minneapolis, MN: University of Minnesota Press.

Diefendorf, B. 1987. Simon Vigor: A Radical Preacher in Sixteenth-Century Paris. The Sixteenth Century Journal 18(3): 399-410.

Doquang, M. 2011. The Lateral Chapels of Notre-Dame in Context. Gesta 50(2): 137-61.

Easton, M. and J. Borland. 2018. Integrated Pasts: Glencairn Museum and Hammond Castle. Gesta 57(1): 95-118.

Erlande-Brandenburg, A. 1998. Notre-Dame de Paris. New York: Harry N. Abrams, Inc.

L'Estoile, Pierre de. 1992. Registre-Journal du règne de Henri III, eds. M. Lazard and G. Schrenck, 6 vols. Genève, Switzerland: Droz. 
Execution remarquable d'un nommé François Sarazin, natif de la Ville de Caën, lequel a assassin M. Berne, Abbé de Rennes en Bretagne, dans l'Eglise Nostre-Dame de Paris, en élevant le Corps \& sang de Jesus-Christ. 1670. Paris, France.

Lyons, K. and M. Busby. 2019. Cathedral fire under control after spire and roof destroyed as it happened. Liveblog. Guardian. https:/www.theguardian.com/world/live/2019/apr/ 15/notre-dame-cathedral-fire-paris-france-landmark-live-news.

Media Indigena. 2019. Episode 158: The Indigenous 'Grief Gap' over the Notre Dame Cathedral Fire. mediaindigena.libsyn.com.

Nicholls, D. 1988. The Theatre of Martyrdom in the French Reformation. Past and Present 121: 49-73.

Payne, T. 2016. A Conductus, an Organum, and a Very Poor Loser: Philip the Chancellor, Pérotin, and the Paris Bishop's Election of 1227-28. Paper presented at the American Musicological Society Annual Conference. Vancouver, Canada.

Sévigné, Mme de, to Mme de Grignan, Paris, 17 July 1676: https://fr.wikisource.org/wiki/ Lettre_du_17_juillet_1676_(S\%C3\%A9vign\%C3\%A9)

Tallon, A. and D. Sandron. 2013. Notre-Dame de Paris: Neuf Siècles de l'Histoire. Paris, France: Parigramme.

Vimalassery, M., J. H. Pegues, and A. Goldstein. 2016. Introduction: On Colonial Unknowing. Theory \& Event 19(4).

Wright, C. 1989. Music and Ceremony at Notre Dame of Paris, 500-1500. Cambridge, UK: Cambridge University Press.

Yudkin, J. 1985. The Music Treatise of Anonymous IV: A New Translation. Stuttgart, Germany: Hänssler-Verlag.

Publisher's Note Springer Nature remains neutral with regard to jurisdictional claims in published maps and institutional affiliations. 